\title{
THE PROFITABILITY OF THE WEEKEND EFFECT: EVIDENCE FROM THE TAIWAN MUTUAL FUND MARKET
}

\author{
Mei-Chen Lin \\ Department of Finance, National United University, Miao Li 36003, Taiwan. \\ Miawjane Chen \\ Department of Finance, National United University, Miao Li 36003, Taiwan., mjchen@nuu.edu.tw
}

Follow this and additional works at: https://jmstt.ntou.edu.tw/journal

Part of the Business Commons

\section{Recommended Citation}

Lin, Mei-Chen and Chen, Miawjane (2008) "THE PROFITABILITY OF THE WEEKEND EFFECT: EVIDENCE FROM THE TAIWAN MUTUAL FUND MARKET," Journal of Marine Science and Technology. Vol. 16: Iss. 3, Article 8.

DOI: $10.51400 / 2709-6998.2012$

Available at: https://jmstt.ntou.edu.tw/journal/vol16/iss3/8

This Research Article is brought to you for free and open access by Journal of Marine Science and Technology. It has been accepted for inclusion in Journal of Marine Science and Technology by an authorized editor of Journal of Marine Science and Technology. 


\title{
THE PROFITABILITY OF THE WEEKEND EFFECT: EVIDENCE FROM THE TAIWAN MUTUAL FUND MARKET
}

\author{
Mei-Chen Lin* and Miawjane Chen*
}

Key words: weekend effect, mutual fund, seasonality.

\begin{abstract}
In this research we first investigated the day-of-the-week effect in the Taiwan mutual fund market. The results revealed significantly negative Monday returns and positive Friday returns. This weekend effect did not vary greatly between the early and later periods of the month. In the absence of transaction costs, weekend trading strategies, both simple and complex, can increase returns and moderate risk. Finally, the pattern triggered by macroeconomic news can only partially subsume the weekend effects of fund returns.
\end{abstract}

\section{INTRODUCTION}

Since the documentation of unusual weekend stock returns by French [21], numerous other studies have confirmed the existence of the weekend effect, the Monday effect, and the day-of-the-week effect, for different time periods and different stock return indexes [2, 23,30]. According to the research, the mean market returns on Mondays will be abnormally low and, in general, negative. This anomalous Monday return pattern exists not only in the US stock market, but also in international stock markets $[29,1]$, and holds true for different types of securities [22]. ., $^{2}$

Numerous theories have been proposed to explain the puzzling discovery of persistent negative returns on Mondays. Lakonishok and Levi [37] first attributed this effect to the delay between trading and settlement in stocks and in clearing checks.

Paper submitted 06/20/07; accepted 09/20/07. Author for correspondence: Miawjane Chen (e-mail: mjchen@nuu.edu.tw).

* Department of Finance, National United University, Miao Li 36003, Taiwan.

${ }^{1}$ In Asian markets, the Japanese indexes show negative returns on Tuesday, but no significant day anomalies affect the stock exchange in Hong-Kong, Korea, Taiwan or Singapore [27, 28, 6]. However with different time periods, Ho [25] showed that five Asian Pacific markets, including Hong Kong, Japan, Malaysia, the Philippines and Singapore, had negative Monday returns. Except for Hong-Kong, all the Asian Pacific markets have negative Tuesday trading returns. Finally, all the Asian Pacific markets have positive Wednesday returns. Since economics in Asia are highly dependent on the US economy [32], the negative Tuesday effect is likely a reflection of the Monday effect in the US.

${ }^{2}$ However, recently the weekend effect has disappeared in the US [14] and in most other countries [8, 15]. Wang, Li, and Erickson [52] further showed that the well-known weekend effect is dominant in the last two weeks of the month.
However settlement delays vary from county to country and only partially explained the previous findings [23]. Damodaran [16] showed that firms tend to report bad news on Fridays, and suggested that these delayed announcements might be the cause of the negative Monday effect. Similarly, only a small proportion of the weekend effect can be explained by this argument [13, 14]. Chang et al. [8, 9] examined the pattern of macroeconomic news releases but again the evidence was weak. Lakonishok and Levi [37], Kamara [31], and Chan, Leung, and Wang [7] reported that individual's intention to increase trading activity (especially sell transactions) on Monday, is an important factor triggering the Monday effect. Sias and Starks [49] found that the weekend patterns of returns and volumes for securities are more pronounced where institutional investors play a greater role. In a recent paper, Chen and Singal [10] further argued that speculative short sellers contribute to the weekend effect.

In comparison to the extensive documentation and analysis of the weekend effect on equity returns, little attention has been paid to this issue in relation to mutual fund returns. There are a number of reasons, including those provided, to explain seasonality in equity market returns, and why the performance of fund managers may vary across calendar days. For example, unfavorable news releases on the weekend, and overreaction as a result of human psychology have an effect on both stock prices and mutual fund performance. In addition, the weekend patterns of returns and volumes are more pronounced for securities in which institutional investors play a greater role [49].

In recent years, some studies have started to investigate the seasonality of mutual fund returns. Zweig [53] was first to demonstrate year-end seasonality in equity funds. In addition to year-end seasonality, Carhart, Kaniel, Musto, and Reed [5] further present evidence that fund managers inflate quarter-end portfolio prices through the aggressive trading of stocks already held during the quarter's last few minutes. In respectively of year-end or quarterly-end seasonality, the magnitude of price inflation is more prevalent in mall-cap funds and the incentives to mark up come from the convex relation between net new investment and performance. More recently, Miller, Prater, and Mazumder [41] examined the patterns of ten open-end mutual funds and revealed the profitability of trading strategies based on the weekend effect.

According to Securities Investment Trust and Consulting Association of the R.O.C. (SITCA), the number of open-ended equity funds and the total TNA for the open-ended equity funds 
have increased steadily during the past decades. Specifically, at the end of June 2006, there were 249 open-ended equity funds in the Taiwan market, with managed assets reaching NT $\$ 400$ billion. This investing trend encouraged many mutual fund investors to pour their money into mutual funds, either as a periodic payment or a lump sum payment. The total for buying mutual funds reached about 1.467 million by the end of June 2006. This indicated that mutual funds had became one of the most popular investment instruments. In additional, the large variety of funds and size of their managed assets has meant they play a significant role in the Taiwan stock market. This is why the first objective of this research is to investigate the day-of-the-week effect in Taiwan mutual fund markets. A weekend effect may provide investors a clue as to the most appropriate time to invest a lump sum payment. The second and third objectives of this study are to explore how the weekend effects on mutual funds are related to the week-of-month and the month-of-year effects. This was motivated by a few studies of the weekend effect reporting that Monday returns are not evenly distributed over the weeks of the month [52] or the months of the year [35]. Besides, if fund performance does indeed exhibit time variation throughout the days of the week, then this can provide potentially useful information to investors as to what period represents the best time to buy and sell units of mutual funds. Therefore, the fourth goal is to examine the predictability of and profitable trading opportunities arising from the weekend effect. The results provide evidence of the Monday effect and Friday effect for all types of funds. Additionally, the weekend effect did not vary with the first or later period of month. In the absence of transaction costs, it was profitable to adopt a strategy based on the patterns of daily returns among days of the week.

This remainder of the paper proceeds in the following manner The next section contains a literature review. The methodology and empirical results are then outlined. Next, a robust test considering the effect from the arrival pattern of macroeconomic news is presented. Finally, some conclusions are given.

\section{LITERATURE REVIEW ON MUTUAL FUND SEASONALITY}

As argued by Carhart, Kaniel, Musto, and Reed [5], it is not redundant to measure the seasonality of equity-fund returns because the return on an equity fund is fundamentally different from the equity return. Specifically, an equity return is calculated from the prices at which the investor bought and sold of. Since stock prices change continuously, investors will receive different equity returns when they trade at different time of the day. An equity-fund return represents the difference between two net asset values (NAVs), which are calculated from the closing prices of the fund's holdings on their respective primary exchanges. The NAV is the actual transaction price used for purchases and redemptions of fund shares after the close of that trading day. Because an investor is unlikely to trade all of the fund's equity positions at the closing prices used to compute the NAVs, the NAVs can depart from the fair value of fund shares whenever equities' closing prices depart from their equilibrium values. When the departure pattern is predictable, investors can benefit from the funds' other shareholders. For example, by estimating the magnitude of market moves between non-US and US market closes for international funds, opportunities for profit can be created [41].

Intuitively, mutual funds are portfolios that gather cash from investors which are then invested in other financial assets. Therefore, the predictability of the price of financial assets (especially in stock prices) would also produce predictability of the NAVs of a mutual fund [44, 45]. Miller, Prater, and Mazumder [41] argued that for mutual fund trading the weekend effect lacks the self-correcting nature of stocks. Specifically, if one investor realizes that stock prices will rise by a significant amount on Friday, then buying stocks at Thursday's closing price and selling them at Friday's closing price will lead to some profits. However, if many investors find and use this profitable trading rule, their trading will eliminate the profits by raising Thursday's closing price and lowering Friday's closing price. As a result, any effort to exploit profits obtained from the predictability will be useless, so that the trading profits are offset by transaction costs [42].

Similar to individual stock investors, a mutual fund investor can also make profits by buying mutual funds of Thursday's NAV and selling them at Friday's NAV. However, for mutual fund this trading strategy will not eliminate the effect as observed in stocks. This is because the fund manager does not have the cash inflows at the time point where the fund's NAVs are calculated and the trades are actually conducted. If fund managers expected a certain fund inflow pattern and take no action until the new funds are received, profitability may continue, since no actions has been taken to affect stock prices. In fact, if fund managers respond to these new fund inflows on Thursday by buying more stocks on Friday, the effect will either continue (when the buying is insufficient) or accentuate the profitability (when the buying is large enough to cause the Friday closing prices of the underlying stocks of mutual funds to increase, which in turn raises the fund's Friday NAV) [42]. In addition, since mutual fund investors can transfer between funds in the same fund family at no expense, they can avoid transaction costs such as bid-ask bounce and commissions. ${ }^{3}$

Zweig [53] found that equity funds outperformed the S\&P 500 on the year's last trading day and underperformed it on the following year's first trading day. The phenomenon was more prevalent for mall-cap funds. In particular, the price shifts of small-cap funds do not match with those of small-cap equity indices, which generally beat the market on both two days around the turn of the year. In addition to year-end seasonality, Carhart, Kaniel, Musto, and Reed [5] further presented evidence that fund managers inflate quarter-end portfolio prices through the aggressive trading of stocks already held in the quarter's last few minutes. The magnitude of price inflation is quite large for small-cap funds. The best-performing funds, controlled for size and performance, show significantly higher price inflation, which implies that the mark up incentives comes from the convex relationship between the net new investment

\footnotetext{
${ }^{3}$ Some fund families may restrict the frequency of trades or impose fees.
} 
and performance.

\section{METHODOLOGIES AND EMPIRICAL RESULTS}

The mutual fund samples were obtained from the Taiwan Economic Journal, a private data vendor. The TEJ database contains data on daily net asset value, fees, load, year of origin, fund category, and other characteristics of the fund. In this study, the data period of open-end equity funds covering from January 1986 to June 2006 were examined.

\section{Traditional Weekend Effect}

We were motivated to extend the evidence of the weekend effect on mutual funds and the industry effect discussed in several places in the literature by examining different fund styles. For instance, Liano and Gup [40] reported that Monday return patterns tend to be dissimilar in different stages of the business cycle, with stronger negative Monday returns during economic contractions than during economic expansions. The above findings combined with the fact that different industries have different business cycles reveal that the weekend effect may be different across industries, and thus different for different types of fund styles. ${ }^{4}$

The hypothesis to be tested relates to the equality of mean returns across five days (six days before the year 2000). In other words, the null hypothesis is that mean returns across all five (or six) days will not exhibit statistically significant differences. To compliment this, Table 1 reports the average returns for all days of the month. Table 1 shows the average returns in percentage, standard deviation, and absolute t-statistics for various fund styles. If the returns are the same for the different days of the week, the F statistics should be insignificant different from zero. As can easily be seen, the F statistics are all significantly different from zero at the 0.05 significance level, regardless of the fund type. This reveals that fund returns vary with the days of the week. This table also provides evidence of the Monday effect and the Friday effect for all types of funds. In particular, all types of funds exhibit significant negative returns on Monday, regardless of the sample period. Inspection of the table also shows that there are differences in the daily returns for the non-Monday days of the week. The average Wednesday and Friday returns are positive, irrespective of the fund types or sample period. Except for the technology- and value-type funds, which have negative returns during the first sample period and positive returns for the second sample, all other types of funds have negative Tuesday returns. For all types of funds, the average Thursday returns are positive, being negative during the first sample period and positive for the second sample. For all funds in the full sample, the average Friday returns are marginally larger than those on Saturday and Wednesday. The dif-

\footnotetext{
${ }^{4}$ It has been documented in the financial literature that earnings announcements and dividend change announcements made by one firm may affect the stock prices of other firms in the same industry [26, 20, 19]. If earnings announcements, dividend change announcements, or business cycles are the reasons for the Monday return patterns, the weekend effect may be different from fund styles. In contrast, if macroeconomic events are the reason for the Monday effects, similar patterns will be observed for different fund styles.
}

ferences between Friday and Wednesday returns widened during the second period, when trading did not occur on Saturday. Finally, irrespective of the sample period and fund style, average Monday returns are always worse than the average Tuesday returns. In sum, there appears to be a Monday effect and a Friday effect in the Taiwan mutual fund market. These differences in returns seem large enough to be potentially exploitable.

Following French [21], Gibbons and Hess [23], and Keim and Stambaugh [33, 34], we also construct a test for differences in mean returns across Monday and Friday (Saturday) by computing the following regression for each mutual fund:

$$
\begin{gathered}
R_{i t}=\alpha_{0}+\alpha_{1}^{\text {Monday }}+\alpha_{2}^{\text {Friday }}+\varepsilon_{i t} \text { after the Year } 2000 \\
\left(R_{i t}=\alpha_{0}+\alpha_{1}^{\text {Monday }}+\alpha_{2}^{\text {Saturday }}+\varepsilon_{i t}\right. \text { before the Year 2000), }
\end{gathered}
$$

where $\mathrm{R}_{\mathrm{it}}$ is the daily returns for fund $\mathrm{i}$ at time $\mathrm{t}, \alpha_{0}$ is the intercept term. The estimate of the coefficient $\alpha_{1}$ represents the rate of return for Monday. The estimate of the coefficient $\alpha_{2}$ represents the rate of return for Friday (Saturday). A significantly negative $\alpha_{1}$ provides evidence of Monday seasonality. An F-statistic is computed for each regression and is reported in the later part of the panel. If the returns are the same for Monday and Friday (Saturday), then the estimates of $\alpha_{1}$ and $\alpha_{2}$ will be equal, and the $\mathrm{F}$ statistics of the regression should be insignificantly different from zero. To investigate the existence of the weekend effect for the various fund styles, we examine the daily returns for six different fund styles, including China-style, general-style, medium-small-style, special-style, technology-style, and value-style. The results are reported in Panel A of Table 2. The coefficients and p-value for all types of funds during the full sample period are shown. The results indicate that, except for the China-related funds, the average Monday returns are significantly negative. Additionally, except for the general-type funds and special-type funds, the other funds have prevalently positive Friday returns. These results are consistent with the weekend effect.

\section{Weekend Effect: An Analysis by Week of the Month}

Ariel [3] analyzed another anomaly in equity returns, the so-called monthly effect, namely that a significantly positive return is generated during the first half of a trading month. Lakonishok and Smidt [38] reported that significant mean daily returns are consistently realized on only four consecutive trading days of the calendar month, beginning with the last trading day of the month. These trading days are henceforth referred to as the turn-of-month trading days. Ogden [46] further asserted that the standardization of payments in the US at the turn of each month caused a surge in stock returns at the turn of each month. Jaffe and Westerfield [27, 28] attempted to detect a monthly effect in international markets, their findings for other countries like Japan, Canada, and the United Kingdom did not support Ariel's. Only in Australia did they find a weak monthly effect pattern in terms of stock returns. 
Table 1. Day-of-the-week descriptive statistics.

\begin{tabular}{|c|c|c|c|c|c|c|c|c|c|}
\hline & Return & Std. & t-value & Return & Std. & t-value & Return & Std. & t-value \\
\hline & \multicolumn{3}{|c|}{ All period } & \multicolumn{3}{|c|}{ 1986-2000 } & \multicolumn{3}{|c|}{$2001-2006 / 6$} \\
\hline \multicolumn{10}{|l|}{ All funds } \\
\hline Monday & -0.1612 & 1.7724 & -25.478 & -0.1903 & 1.7621 & -19.181 & -0.1416 & 1.7791 & -17.248 \\
\hline Tuesday & -0.0412 & 1.5481 & -7.448 & -0.0616 & 1.6476 & -6.639 & -0.0274 & 1.4774 & -4.023 \\
\hline Wednesday & 0.1323 & 1.6127 & 22.975 & 0.1304 & 1.6569 & 13.973 & 0.1335 & 1.5823 & 18.284 \\
\hline Thursday & 0.0081 & 1.5319 & 1.474 & -0.0697 & 1.6300 & -7.594 & 0.0603 & 1.4600 & 8.949 \\
\hline Friday & 0.1489 & 1.4899 & 27.995 & 0.0913 & 1.5893 & 10.202 & 0.1876 & 1.4180 & 28.661 \\
\hline \multirow[t]{2}{*}{ Saturday } & 0.1310 & 1.2172 & 19.114 & 0.1310 & 1.2172 & 19.114 & NA & NA & NA \\
\hline & \multicolumn{3}{|c|}{$\mathrm{F}=478.01 \mathrm{P}$-value $<.0001$} & \multicolumn{3}{|c|}{$\mathrm{F}=230.89 \mathrm{p}$-value $<.0001$} & \multicolumn{3}{|c|}{$\mathrm{F}=278.79 \mathrm{p}$-value $<.0001$} \\
\hline \multicolumn{10}{|l|}{ China-related } \\
\hline Monday & -0.0788 & 1.6927 & -1.839 & NA & NA & NA & -0.0788 & 1.6927 & -1.839 \\
\hline Tuesday & -0.0563 & 1.2877 & -1.727 & NA & NA & NA & -0.0563 & 1.2877 & -1.727 \\
\hline Wednesday & 0.0866 & 1.4349 & 2.385 & NA & NA & NA & 0.0866 & 1.4349 & 2.385 \\
\hline Thursday & 0.0325 & 1.3132 & 0.979 & NA & NA & NA & 0.0325 & 1.3132 & 0.979 \\
\hline Friday & 0.1908 & 1.2860 & 5.863 & NA & NA & NA & 0.1908 & 1.2860 & 5.863 \\
\hline \multirow[t]{2}{*}{ Saturday } & NA & NA & NA & NA & NA & NA & NA & NA & NA \\
\hline & \multicolumn{3}{|c|}{$\mathrm{F}=10.05 \mathrm{p}<.0001$} & & & & \multicolumn{3}{|c|}{$\mathrm{F}=10.05 \mathrm{p}<.0001$} \\
\hline \multicolumn{10}{|l|}{ General } \\
\hline Monday & -0.1540 & 1.7447 & -19.425 & -0.1771 & 1.7217 & -15.377 & -0.1342 & 1.7640 & -12.288 \\
\hline Tuesday & -0.0438 & 1.5299 & -6.305 & -0.0700 & 1.6000 & -6.545 & -0.0214 & 1.4667 & -2.352 \\
\hline Wednesday & 0.1343 & 1.5920 & 18.561 & 0.1411 & 1.6193 & 13.032 & 0.1284 & 1.5682 & 13.221 \\
\hline Thursday & 0.0053 & 1.5228 & 0.767 & -0.0521 & 1.6000 & -4.867 & 0.0545 & 1.4516 & 6.062 \\
\hline Friday & 0.1364 & 1.4807 & 20.271 & 0.0884 & 1.5618 & 8.464 & 0.1775 & 1.4063 & 20.384 \\
\hline \multirow[t]{2}{*}{ Saturday } & 0.1439 & 1.2016 & 17.900 & 0.1439 & 1.2016 & 17.900 & NA & NA & NA \\
\hline & \multicolumn{3}{|c|}{$\mathrm{F}=296.75 \mathrm{P}$-value $<.0001$} & $\mathrm{~F}=171.3$ & $\mathrm{p}<.0001$ & & $\mathrm{~F}=175.2$ & $\mathrm{p}<.0001$ & \\
\hline Mid-and-small & & & & & & & & & \\
\hline Monday & -0.1033 & 1.7945 & -4.533 & -0.0742 & 1.7980 & -2.586 & -0.1537 & 1.7878 & -4.098 \\
\hline Tuesday & -0.0405 & 1.5724 & -2.027 & -0.0405 & 1.6079 & -1.581 & -0.0403 & 1.5092 & -1.273 \\
\hline Wednesday & 0.0931 & 1.5866 & 4.620 & 0.0681 & 1.5721 & 2.716 & 0.1363 & 1.6108 & 4.033 \\
\hline Thursday & 0.0041 & 1.5508 & 0.208 & -0.0443 & 1.5817 & -1.758 & 0.0879 & 1.4925 & 2.808 \\
\hline Friday & 0.1110 & 1.5134 & 5.774 & 0.0790 & 1.5488 & 3.197 & 0.1663 & 1.4487 & 5.472 \\
\hline Saturday & 0.1092 & 1.1571 & 5.919 & 0.1092 & 1.1571 & 5.919 & NA & NA & NA \\
\hline & $\mathrm{F}=57.11$ & $0<.0001$ & & $\mathrm{~F}=15.55$ & $p<.0001$ & & $\mathrm{~F}=57.94$ & $\mathrm{p}<.0001$ & \\
\hline Special & & & & & & & & & \\
\hline Monday & -0.1655 & 1.8146 & -8.050 & -0.2231 & 1.8822 & -5.045 & -0.1480 & 1.7934 & -6.382 \\
\hline Tuesday & -0.0638 & 1.5903 & -3.541 & -0.1253 & 1.8572 & -2.872 & -0.0452 & 1.4997 & -2.328 \\
\hline Wednesday & 0.1511 & 1.6679 & 7.995 & 0.0997 & 1.8505 & 2.291 & 0.1667 & 1.6084 & 8.013 \\
\hline Thursday & 0.0247 & 1.5289 & 1.425 & -0.1096 & 1.7367 & -2.688 & 0.0655 & 1.4577 & 3.471 \\
\hline Friday & 0.1903 & 1.4872 & 11.293 & 0.0858 & 1.6515 & 2.211 & 0.2220 & 1.4323 & 11.983 \\
\hline Saturday & 0.1372 & 1.3118 & 4.456 & 0.1372 & 1.3118 & 4.456 & NA & NA & NA \\
\hline & $F=23.67$ & $\mathrm{p}<.0001$ & & $\mathrm{~F}=14.49$ & $\mathrm{p}<.0001$ & & $\mathrm{~F}=17.19$ & $\mathrm{p}<.0001$ & \\
\hline Technology & & & & & & & & & \\
\hline Monday & -0.2186 & 1.8592 & -13.201 & -0.3629 & 1.8991 & -10.747 & -0.1702 & 1.8432 & -8.977 \\
\hline Tuesday & -0.0125 & 1.6230 & -0.866 & 0.0062 & 1.8718 & 0.186 & -0.0188 & 1.5308 & -1.192 \\
\hline Wednesday & 0.1390 & 1.7013 & 9.172 & 0.1623 & 1.8744 & 4.865 & 0.1312 & 1.6393 & 7.779 \\
\hline Thursday & 0.0058 & 1.5998 & 0.405 & -0.1781 & 1.8088 & -5.533 & 0.0672 & 1.5186 & 4.304 \\
\hline Friday & 0.1764 & 1.5484 & 12.794 & 0.1115 & 1.7634 & 3.556 & 0.1982 & 1.4689 & 13.111 \\
\hline Saturday & 0.0982 & 1.3253 & 4.166 & 0.0982 & 1.3253 & 4.166 & NA & NA & NA \\
\hline & $\mathrm{F}=89.33$ & $\mathrm{p}<.0001$ & & $\mathrm{~F}=37.61$ & $\mathrm{p}<.0001$ & & $\mathrm{~F}=77.02$ & $\mathrm{p}<.0001$ & \\
\hline Value & & & & & & & & & \\
\hline Monday & -0.2051 & 1.6887 & -5.238 & -0.7414 & 1.8222 & -6.548 & -0.1183 & 1.6504 & -2.869 \\
\hline Tuesday & -0.0611 & 1.4426 & -1.825 & 0.0238 & 1.7540 & 0.219 & -0.0748 & 1.3859 & -2.159 \\
\hline Wednesday & 0.1245 & 1.5261 & 3.517 & 0.0196 & 1.8427 & 0.171 & 0.1414 & 1.4687 & 3.852 \\
\hline Thursday & 0.0206 & 1.4234 & 0.623 & -0.4214 & 1.7490 & -3.870 & 0.0918 & 1.3509 & 2.718 \\
\hline Friday & 0.2084 & 1.4116 & 6.367 & 0.3130 & 1.8626 & 2.705 & 0.1915 & 1.3243 & 5.786 \\
\hline Saturday & -0.2859 & 1.3032 & -3.530 & -0.2859 & 1.3032 & -3.530 & NA & NA & NA \\
\hline & $\mathrm{F}=18.74$ & $\mathrm{p}<.0001$ & & $\mathrm{~F}=11.09$ & $\mathrm{p}<.0001$ & & $\mathrm{~F}=15.44$ & $<.0001$ & \\
\hline
\end{tabular}

*This table presents the average returns in percentages, standard deviations in percentages, and absolute t-statistics for all-types of funds during the full sample period and for the two sub-samples. The t-statistics are for the test of the null hypothesis that the average returns for that day of the week well be equal to zero. The sample period ranges from January 1986 to June 2006. 
Table 3. Test of traditional weekend effect during different time period.

\begin{tabular}{rrrrrrrr}
\hline & All funds & \multicolumn{1}{c}{ China } & \multicolumn{1}{c}{ GEL } & Mid-and-small & Special & Technology & Value \\
\hline \multirow{7}{*}{ Intercept } & 0.0436 & NA & 0.0453 & 0.0469 & 0.0259 & 0.0492 & NA \\
& $(<.0001)$ & NA & $(<.0001)$ & $(<.0001)$ & $(0.0951)$ & $(<.0001)$ & NA \\
Monday & -0.2495 & NA & -0.2524 & -0.2233 & -0.2545 & -0.2796 & NA \\
& $(<.0001)$ & NA & $(<.0001)$ & $(<.0001)$ & $(<.0001)$ & $(<.0001)$ & NA \\
Friday & 0.0996 & NA & 0.0829 & 0.1324 & 0.0832 & 0.1143 & NA \\
& $(<.0001)$ & NA & $(<.0001)$ & $(<.0001)$ & $(0.0048)$ & $(<.0001)$ & NA \\
Adjusted R2 & 0.0048 & NA & 0.0046 & 0.0046 & 0.0044 & 0.0057 & NA \\
\hline \multirow{7}{*}{ Intercept } & 0.0434 & 0.0260 & Panel B: Year 1997 to year 2006 & & & \\
& $(<.0001)$ & $(0.1883)$ & $(<.0001)$ & $(0.9358)$ & $(0.0242)$ & $(0.0227)$ & $(0.5979)$ \\
Monday & 0.0101 & -0.1048 & 0.0007 & 0.3165 & 0.0501 & $(-0.0706)$ & -0.2158 \\
& $(0.4778)$ & $(0.0271)$ & $(0.9667)$ & $(0.0473)$ & $(0.1704)$ & 0.3432 & $(<.0001)$ \\
Friday & 0.1132 & 0.1692 & 0.1174 & 0.2102 & 0.0815 & $(0.1461)$ & 0.1862 \\
& $(<.0001)$ & $(<.0001)$ & $(<.0001)$ & $(0.1070)$ & $(0.0145)$ & 0.0295 & $(<.0001)$ \\
Adjusted R2 & 0.0008 & 0.0036 & 0.0009 & 0.0037 & 0.0003 & $(0.0011)$ & 0.0065 \\
\hline
\end{tabular}

* Panel A and B show the results of the following regressions during Year 1986 to 1996 and Year 1997 to 2006, respectively:

$$
R_{i t}=\alpha_{0}+\alpha_{1} D M O N_{t}+\alpha_{2} D F R I_{t}+\mu_{i t}
$$

where $R_{i t}$ is the return of mutual fund $\mathrm{i}$ on day $\mathrm{t}$; $\mathrm{DMON}_{\mathrm{t}}$ is a dummy variable that equals to one if day $\mathrm{t}$ is a Monday, and is zero otherwise; $\mathrm{DFRI}_{\mathrm{t}}$ is a dummy variable that equals to one if day $\mathrm{t}$ is a Friday (Saturday before 2000), and is zero otherwise.

Wang, $\mathrm{Li}$, and Erickson [52] showed that the weekend effect occurs primarily in the last two weeks of the month. It appears that the Monday effect may be related to the week of the month. To address whether the Monday effect is concentrated in the last two weeks of the month, we partition the daily returns by the day-of-the-week (Monday return and Tuesday to Friday returns), and by the first-half of the month and the last-half of the month. The differences in mean returns between the first-half and the last-half of the month are then analyzed. The following regression is then run:

$$
\begin{aligned}
& R_{i t}=\alpha_{0}+\alpha_{1} D_{M O N_{t}}+\alpha_{2} D_{F R I_{t}}+\mu_{i t} \\
& R_{i t}=\beta_{0}+\beta_{1} D M O N_{t}+\beta_{2} D F R I_{t}+\beta_{3} D L T W_{t} \\
& +\beta_{4} \text { DMON }_{t} D L T W_{t}+\beta_{5} \text { DFRI }_{t} D_{F T W_{t}}+\varepsilon_{i t},
\end{aligned}
$$

where $R_{i t}$ is the return of mutual fund i on day $\mathrm{t}$; $\mathrm{DMON}_{\mathrm{t}}$ is a dummy variable that is equal to one if day $\mathrm{t}$ is a Monday, and is zero otherwise; DFRI $I_{t}$ is a dummy variable that is equal to one if day $\mathrm{t}$ is a Friday, and is zero otherwise; DLTW $_{\mathrm{t}}$ is a dummy variable that is equal to one if day $t$ is in the last two weeks in a month, and is zero otherwise; DMON $_{t}$ DLTW $_{t}$ is a dummy variable that is equal to one if day $t$ is a Monday and is in the last two weeks in a month, and is zero otherwise. DFRI $\mathrm{t}_{\mathrm{t}}$ DFTW $_{t}$ is a dummy variable that is equal to one if day $t$ is Monday and is in the last two weeks in a month, and is zero otherwise. The coefficient $\beta_{1}$ measures the Monday returns for the first-two-week days. Coefficient $\beta_{2}$ measures the Friday returns in the last-two-week days. Coefficient $\beta_{3}$ meas- ures the non-Monday returns for the last-two-week days. Coefficient $\beta_{4}$ measures the Monday returns for the last-two-week days. Coefficient $\beta_{5}$ measures the Friday returns for the first-two-week days. Since the residuals of all the regressions suffer from both autocorrelation and heteroskedasticity, the t-statistics are corrected using Newey-West's [43] heteroskedasticity and autocorrelation consistent covariance matrix. The results are reported in Panel B of Table 2. As predicted, the regression shows that the coefficient on "last half month" is significantly negative. In particular, the Monday returns on the last half-month are pronounced positive $\left(\beta_{4}>0\right)$. This result is consistent with Wang, $\mathrm{Li}$, and Erickson [52], namely that the weekend effect occurs primarily in the last two weeks of the month. By contrast, except for the general-type and value-type funds, the Friday returns for the first-half of the month are significantly larger than those for the second-half of the month $\left(\beta_{5}>0\right)$. That is, the cash flows during the early period of a month have an effect on the value of the stocks and thereby the fund shares. In particular, the significantly negative $\beta_{1}$ and $\beta_{4}$ coefficients indicate that the negative Monday returns exist in both the first and the latter half month. Likewise, both the $\beta_{2}$ and $\beta_{5}$ coefficients are significantly positive, which reveals that positive Friday returns exist in all parts of the month. In other words, the negative Monday returns and positive Friday returns did not vary whether in the first or latter part of the month.

The weekend effect discussed in so much of the literature seems to have vanished in recent years $[14,8,15]$. In this study 
Table 4. Test of weekend effect by week of the month during different time period.

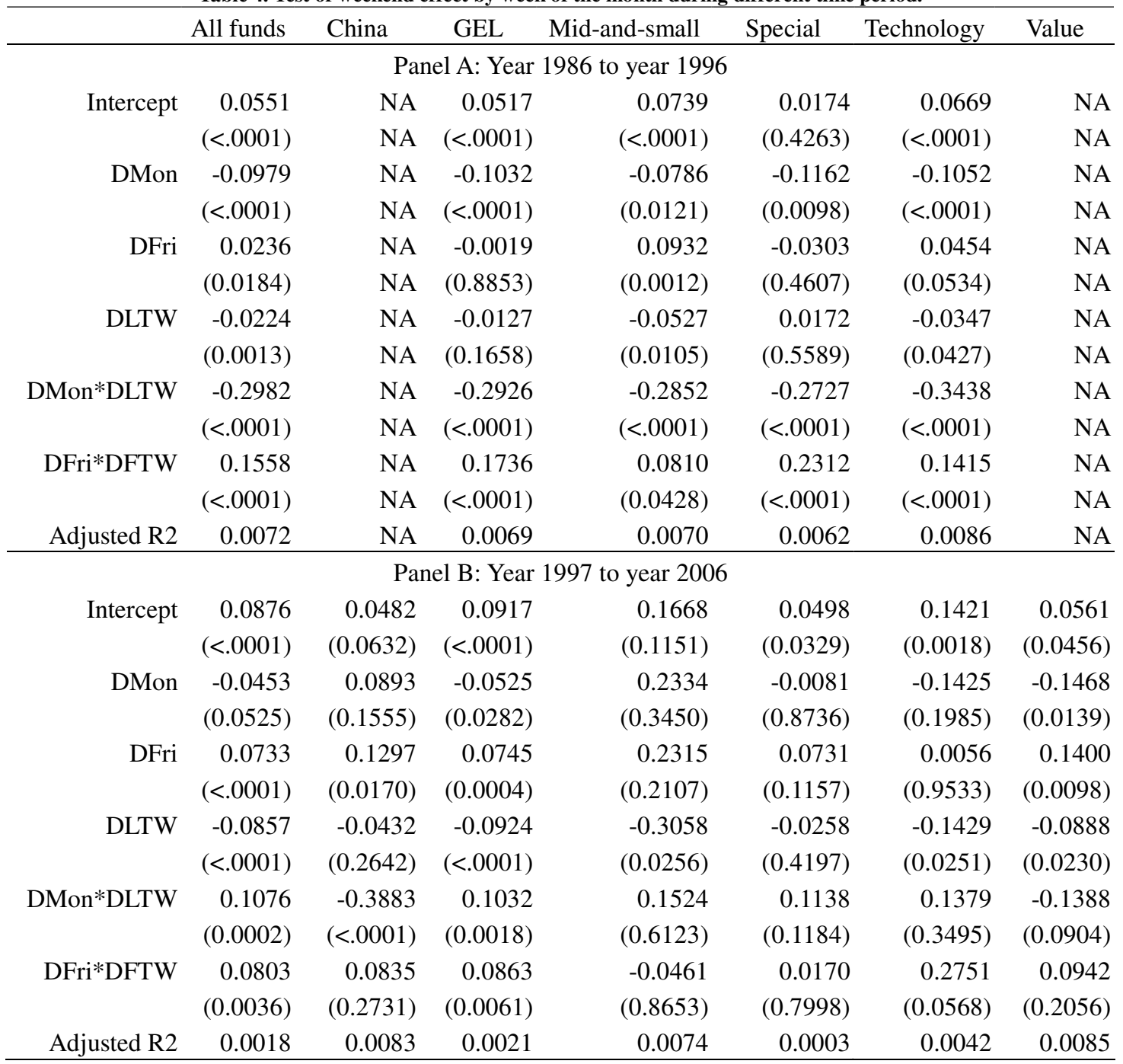

* In this table, year dummies are included to consider a vanishing weekend effect in recent years. Likewise, to address if the Monday effect is concentrated in the last two weeks of the month, I partition the daily returns by the day-of-the-week (Monday return and Tuesday to Friday returns (Saturday returns before 2000)) and by the first-half of the month and the last-half of the month to analyze the differences in mean returns between the first-half and the last-half of the month. Panel A and B show the results of the following regressions during Year 1986 to 1996 and Year 1997 to 2006, respectively:

$$
R_{i t}=\beta_{0}+\beta_{1} D_{M O N}+\beta_{2} D F R I_{t}+\beta_{3} D L T W_{t}+\beta_{4} D_{M O N} D L T W_{t}+\beta_{5} D_{F R I} D F T W_{t}+\varepsilon_{i t}
$$

where $R_{i t}$ is the return of mutual fund $\mathrm{i}$ on day $\mathrm{t}$; $\mathrm{DMON}_{\mathrm{t}}$ is a dummy variable that equals to one if day $\mathrm{t}$ is a Monday, and is zero otherwise; $\mathrm{DFRI}$ is a dummy variable that equals to one if day $\mathrm{t}$ is a Friday (Saturday before 2000), and is zero otherwise; DLTW $\mathrm{t}$ is a dummy variable that equals to one if day $\mathrm{t}$ is one of the last two weeks in a month, and is zero otherwise.

we further examine whether or not the seasonality of mutual fund returns has also disappeared with the passage of time passed. In Panels A and B of Table 3 the results of traditional weekend effect testing for 1986 to 1996 and 1997 to 2006 are reported.

As predicted, there were profoundly negative Monday returns and significantly positive Friday returns during period one (1986 to 1996) but in period two (1997 to 2006), Monday returns became insignificant. The results for the test of the weekend effect by week of the month are shown in Table 4. Likewise, it can be seen that the Monday returns are also significantly negative for period one. Although the Monday re- turns are still negative for period two, their significance decreases to become marginally significant at the $10 \%$ significance level. These findings confirm previous research that the weekend effect vanished in recent years.

\section{Trading Strategy}

This section is aimed at exploring the profitability via the patterns of daily returns for the days of the week. Based on the results in Table 1, two trading rules are established. The first follows French [21], Kim [36], Chow, Hsiao, and Solt [11], and Compton and Kunkel [12]. This simple trading rule is that investors shift their money into a money market fund on Friday to avoid the negative Monday return and then switch it back to 
Table 5. Profitability of various strategies from the patterns of daily returns.

\begin{tabular}{|c|c|c|c|c|c|c|c|c|}
\hline & Strategy & $\begin{array}{c}\text { All } \\
\text { funds }\end{array}$ & China-related & General & Mid-and-small & Special & Technology & Value \\
\hline \multirow[t]{3}{*}{ Return } & Buy-and-Hold & 0.0325 & 0.0265 & 0.0316 & 0.0378 & 0.0287 & 0.0325 & 0.0384 \\
\hline & Simple & 0.0518 & 0.0407 & 0.0497 & 0.0606 & 0.0500 & 0.0545 & 0.0491 \\
\hline & Complex & 0.0596 & 0.0485 & 0.0573 & 0.0683 & 0.0600 & 0.0618 & 0.0626 \\
\hline \multirow{3}{*}{$\begin{array}{l}\text { Risk } \\
\text { (Std. } \\
\text { Dev) }\end{array}$} & Buy-and-Hold & 1.3266 & 1.1232 & 1.3258 & 1.3268 & 1.3416 & 1.3665 & 1.2247 \\
\hline & Simple & 1.1469 & 0.9493 & 1.1481 & 1.1450 & 1.1642 & 1.1792 & 1.0567 \\
\hline & Complex & 0.9974 & 0.8290 & 0.9984 & 0.9938 & 1.0123 & 1.0264 & 0.9171 \\
\hline \multirow{3}{*}{$\begin{array}{l}\text { Sharpe } \\
\text { ratio }\end{array}$} & Buy-and-Hold & 0.0221 & 0.0221 & 0.0214 & 0.0263 & 0.0187 & 0.0215 & 0.0286 \\
\hline & Simple & 0.0424 & 0.0410 & 0.0404 & 0.0504 & 0.0399 & 0.0437 & 0.0432 \\
\hline & Complex & 0.0566 & 0.0564 & 0.0542 & 0.0657 & 0.0557 & 0.0572 & 0.0645 \\
\hline \multirow{3}{*}{$\begin{array}{l}\text { Treynor } \\
\text { ratio }\end{array}$} & Buy-and-Hold & 0.0454 & 0.0434 & 0.0437 & 0.0556 & 0.0396 & 0.0435 & 0.0589 \\
\hline & Simple & 0.0751 & 0.0682 & 0.0716 & 0.0920 & 0.0733 & 0.0761 & 0.0769 \\
\hline & Complex & 0.0873 & 0.0820 & 0.0834 & 0.1042 & 0.0889 & 0.0867 & 0.0997 \\
\hline
\end{tabular}

* This table gives the daily mean returns (in percentages), standard deviation (risk), and Sharpe and Treynor ratios for the buy-and-hold strategy, simple trading strategy, and complex trading strategy for all asset classes. The simple trading rule is that investors will shift their money into a money market fund on Friday to avoid the negative Monday returns and then switch it back to the riskier mutual fund on Monday. The complex trading rule is that investors will shift their money into a money market fund (or deposits) to avoid the days of the weeks when average returns of the mutual fund class are historically negative and then switch it back to the riskier mutual fund.

the riskier mutual fund on Monday. The second trading rule, proposed by Miller, Prather, and Mazumder [41], is more complex and uses all daily-return-pattern. This complex trading rule is that investors shift their money into bank's deposit to avoid days of the weeks when average returns of the mutual fund class have historically been negative, then switch it back to the riskier mutual fund. From Table 1, it can be seen that investors in all types of funds switch their investments into money market funds (or deposits) to avoid negative Monday and Tuesday returns, because negative returns was displayed by these funds on these two days of the week during the sample period.

In Table 5 the daily mean returns (in percentage), standard deviation (risk), and Sharpe [48] and Treynor [50] ratios for the buy-and-hold strategy, simple trading strategy, and complex trading strategy for all asset classes are reported. The results suggest that both of the trading strategies provide higher daily mean returns than that of the buy-and-hold strategy. The largest daily returns occurred when using the complex trading strategy and for the medium-and-small type funds $(0.0683 \%)$. Investors, who adopted simple trading rules, did not hold risky funds over the weekend or on Monday, while investors using the complex weekend strategy did not hold risky investments over the weekend, or on Monday, or on Tuesday. This means that both trading rules will lower risks and which may be beneficial to investors, allowing them to obtain stronger risk-adjusted returns. Indeed, the two form of trading rule portfolios did lower risks (in terms of the standard deviation) and provide higher returns per unit of risk (Sharpe ratios) than was possible with the buy-and-hold portfolios. Likewise, both trading rules permitted higher returns per unit of systematic risk (Treynor ratios). Altogether, the complex strategy provided the lowest risk for the China-related funds (0.8290). The largest Sharpe ratio and Treynor ratio occurred when using a complex trading strategy with the mid-and-small-cap funds (0.0657 for Sharpe ratio and 0.1042 for Treynor ratio). A comparison of the risks and returns for the complex and the simple trading rules, reveals that the complex rules produced higher daily returns and lower risk regardless of fund types.

Additionally, the Sharpe measures suggest that the reward-to-variability ratios are also better for the complex trading rules. Similarly, the risk-adjusted returns, as measured by the Treynor ratio, are stronger for the complex trading rules.

The Jensen measures for the buy-and-hold strategy as well as the simple and complex trading strategies are reported in Table 6. It can be seen that the Jensen alphas are significantly positive for all strategies. Given the fund type, the complex rule produced the highest Jensen alpha among the three strategies. These results hold for all fund types. For a given strategy, the mid-and-small-cap funds always have the highest Jensen alpha. For example, the Jensen alphas are 0.0176 for the buy-and-hold strategy, 0.0451 for the simple strategy, and 0.0558 for the complex strategy. The complex strategy provided the highest and positive Jensen alpha with mid-and-small-cap funds (0.0558). The Sharpe [48], Treynor [51], and Jensen [30] measures of risk-adjusted returns provide good evidence that the complex weekend trading strategy is the best trading strategy for mutual fund investors.

\section{Market Timing Analysis}

The simple and complex trading strategies require the shifting of money between mutual funds and money market funds (or deposits) so as to capture gain in the up markets and avoid losses in the down markets. In this section Treynor-Mazuy (TM) [51] and Henriksson-Merton (HM) [24] market-timing models are used to test whether the performances of the trading strategies comes from fund manager's timing ability. The equations for the TM and HM models, respectively, are:

$$
\begin{aligned}
& T M: R_{p}-R_{f}=\alpha+\beta\left(R_{m}-R_{f}\right)+\gamma\left(R_{m}-R_{f}\right)^{2}+\varepsilon \\
& H M: R_{p}-R_{f}=\alpha+\beta\left(R_{m}-R_{f}\right)+\gamma\left(R_{m}-R_{f}\right) D+\varepsilon
\end{aligned}
$$


Table 6. Jensen measures for returns of buy-and-hold strategy, simple trading strategy and complex trading strategy.

\begin{tabular}{rcccccccccc}
\hline Asset classes & \multicolumn{3}{c}{ Buy and Hold strategy } & \multicolumn{3}{c}{ Simple trading strategy } & \multicolumn{3}{c}{ Complex trading strategy } \\
\hline & $\alpha$ & $\beta$ & $R^{2}$ & $\alpha$ & $\beta$ & $R^{2}$ & $\alpha$ & $\beta$ & $R^{2}$ \\
\hline All funds & 0.0097 & 0.9204 & 0.7419 & 0.0341 & 0.6772 & 0.5374 & 0.0455 & 0.5165 & 0.4134 \\
& $<.0001$ & $<.0001$ & & $<.0001$ & $<.0001$ & & $<.0001$ & $<.0001$ & \\
China-related & 0.0081 & 0.9533 & 0.7192 & 0.0275 & 0.6530 & 0.4724 & 0.0379 & 0.5086 & 0.3757 \\
& 0.2078 & $<.0001$ & & $<.0001$ & $<.0001$ & & $<.0001$ & $<.0001$ & \\
General & 0.0083 & 0.9158 & 0.7548 & 0.0316 & 0.6770 & 0.5500 & 0.0428 & 0.5159 & 0.4224 \\
& $<.0001$ & $<.0001$ & & $<.0001$ & $<.0001$ & & $<.0001$ & $<.0001$ & \\
Mid-and-small & 0.0176 & 0.9087 & 0.6880 & 0.0451 & 0.6629 & 0.4917 & 0.0558 & 0.5044 & 0.3779 \\
& $<.0001$ & $<.0001$ & & $<.0001$ & $<.0001$ & & $<.0001$ & $<.0001$ & \\
Special & 0.0080 & 0.8978 & 0.7223 & 0.0336 & 0.6693 & 0.5332 & 0.0466 & 0.5097 & 0.4090 \\
& 0.1946 & $<.0001$ & & $<.0001$ & $<.0001$ & & $<.0001$ & $<.0001$ & \\
Technology & 0.0085 & 0.9527 & 0.7387 & 0.0362 & 0.6973 & 0.5315 & 0.0470 & 0.5330 & 0.4099 \\
& 0.0042 & $<.0001$ & & $<.0001$ & $<.0001$ & & $<.0001$ & $<.0001$ & \\
Value & 0.0132 & 0.8666 & 0.8066 & 0.0297 & 0.6386 & 0.5884 & 0.0470 & 0.4868 & 0.4540 \\
& 0.0142 & $<.0001$ & & $<.0001$ & $<.0001$ & & $<.0001$ & $<.0001$ & \\
\hline
\end{tabular}

* This table shows the Jensen measures for returns of the buy-and-hold strategy, simple trading strategy and complex trading strategy. The simple trading rule is that investors will shift their money into a money market fund on Friday to avoid the negative Monday returns and then switch it back to the riskier mutual fund on Monday. The complex trading rule is that investors will shift their money into a money market fund (or deposits) to avoid the days of the weeks when average returns of the mutual fund class are historically negative and then switch it back to the riskier mutual fund.

where $R_{p}-R_{f}$ is the excess return from either the simple or the complex trading strategy, $R_{m}-R_{f}$ is market excess return, and $\alpha, \beta$ and $\gamma$ are the coefficients for selectivity (risk-adjusted returns), systematic risk, and market timing, respectively, D is dummy variable that takes a value of 1 if the market return exceeds the risk-free rate or zero if the market return is below the risk-free rate, and $\varepsilon$ is random error term.

As argued by Treynor-Mazuy (TM) [51] and Henriksson-Merton (HM) [24], if fund managers can forecast market returns correctly, they will hold a larger (smaller) proportion of a market portfolio when the market returns are high (low), in which case the coefficient of timing ability, $\gamma$, will be positive in equations (4) and (5). On the other hand, a significantly negative $\gamma$ implies inferior timing ability. A statistically significant positive $\alpha$ is indicates superior selection ability of fund managers.

The results of the TM and HM measures for the buy-and-hold, simple trading, and complex trading strategies are reported in Tables 7 and 8 .

The results for the TM measures in Table 7 suggest that, regardless of the fund type, the buy-and-hold strategy exhibits a significantly negative timing ability $(\gamma)$. This is consistent with the conclusions made in the most of the mutual fund performance literature, namely that mutual funds display perverse market timing ability $[51,24,47]$. By contrast, the TM measures suggest that, irrespective of the fund type, the simple and complex trading strategies exhibit significantly positive timing ability. Similar results are also found for the HM measures in Table 8. Despite these indications of perverse timing of buy and hold strategy, the profitability from the simple and complex trading strategies reveals that perverse timing may not be the result of decisions made by active portfolio managers. ${ }^{5}$ Edelen $[17,18]$ documented that some negative timing ability can be explained by time variation in cash inflows and outflows (e.g., from dividends, rights issues, new subscriptions, and fund redemptions).

The above results indicate that, in the absence of transaction costs, following a weekend trading strategy that incorporates a weekend effect would be profitable. This is consistent with Bollen and Busse [4], namely that mutual fund managers possess greater timing ability than previously reported in the performance literature. Mazumder, Miller and Varela [42] have argued that the success of this trading strategy is due to ability of mutual fund manager to forecast day-of-the-week patterns in security returns, but they can not exploit these due to transaction costs. If investors can also forecast daily return patterns, and are able to trade fund shares at no charge, as well as shift money between mutual funds and money market funds (or deposits) so as to avoid some negative returns on Monday and Tuesday, this may improve their timing performance. ${ }^{6}$

\section{REVISED TESTS FOR WEEKEND EFFECTS}

To test the hypothesis that the arrival pattern of macroeconomic news contributes to weekend fund return effects, similar to Chang, Pinegar, and Ravichandran [8], we use the returns on a value-weighted portfolio of large firms stocks to proxy the

\footnotetext{
${ }^{5}$ Several papers have discussed the extent that mutual fund flows may affect security prices, but not about how fund inflows and outflows may affect fund performance. For example, information released on mutual fund flows, price pressure, and investor sentiments provides some explanation for the relation between fund flows and security price movement [18, 44, 45, 6].

${ }^{6}$ Interestingly, the significantly positive intercepts indicate that mutual fund managers have the ability to select stocks.
} 
Table 7. Treynor and Mazuy (TM) measures for returns of buy-and-hold strategy, simple trading strategy and complex trading strategy.

\begin{tabular}{|c|c|c|c|c|c|c|c|c|c|}
\hline \multirow[t]{2}{*}{ Asset classes } & \multicolumn{3}{|c|}{ Buy and Hold strategy } & \multicolumn{3}{|c|}{ Simple trading strategy } & \multicolumn{3}{|c|}{ Complex trading strategy } \\
\hline & $\alpha$ & $\beta$ & $R^{2}$ & $\alpha$ & $\beta$ & $\gamma \quad R^{2}$ & $\alpha$ & $\beta \quad \gamma$ & $R^{2}$ \\
\hline \multirow[t]{2}{*}{ All funds } & 0.0194 & 0.9216 & -0.00630 .7422 & & 0.6744 & 0.01490 .5397 & 0.0337 & 0.51500 .0076 & 0.414 \\
\hline & $<.0001$ & $<.0001$ & $<.0001$ & $<.0001$ & $<.0001$ & $<.0001$ & $<.0001$ & $<.0001<.0001$ & \\
\hline \multirow[t]{2}{*}{ China-related } & 0.0167 & 0.9514 & -0.00850 .7197 & 0.0090 & 0.6572 & 0.01850 .4 & 0.0231 & 0.51190 .0148 & 0.378 \\
\hline & 0.0081 & $<.0001$ & 0.0007 & 0.2665 & $<.0001$ & 0.0196 & 0.0025 & $<.00010 .0652$ & \\
\hline \multirow[t]{2}{*}{ General } & 0.0174 & 0.9171 & -0.00570 .7551 & 0.0081 & 0.6737 & 0.01490 .5523 & 0.0310 & 0.51420 .0075 & 0.423 \\
\hline & $<.0001$ & $<.0001$ & $<.0001$ & $<.0001$ & $<.0001$ & $<.0001$ & $<.0001$ & $01<.0001$ & \\
\hline \multirow[t]{2}{*}{ Mid-and-small } & 0.0296 & 0.9097 & -0.00810 .6885 & 0.0215 & 0.6609 & 0.01610 .4943 & 0.0449 & 50.0074 & \\
\hline & $<.0001$ & $<.0001$ & $<.0001$ & $<.0001$ & $<.0001$ & $<.0001$ & $<.0001$ & 10.0058 & \\
\hline \multirow[t]{2}{*}{ Special } & 0.0202 & 0.8996 & -0.00760 .7227 & 0.0088 & 0.6655 & 0.01540 .5356 & 0.0342 & 0.50780 .0078 & 0.409 \\
\hline & 0.0006 & $<.0001$ & 0.0005 & 0.1825 & $<.0001$ & 0.00 & $<.0001$ & $<.00010 .0800$ & \\
\hline \multirow[t]{2}{*}{ Technology } & 0.0174 & 0.9536 & -0.00580 .7389 & 0.0145 & 0.6950 & 0.01430 .5335 & 0.0351 & 0.53170 .0079 & $0.410^{7}$ \\
\hline & $<.0001$ & $<.0001$ & $<.0001$ & $<.000$ & $<.0001$ & $<.0001$ & $<.0001$ & $<.00010 .0002$ & \\
\hline \multirow[t]{2}{*}{ Value } & 0.0264 & 0.8687 & -0.00820 .8072 & 0.0110 & 0.6356 & 0.01160 .5901 & 0.0380 & 0.48540 .0056 & 0.454 \\
\hline & $<.0001$ & $<.0001$ & $<.0001$ & 0.1188 & $<.0001$ & 0.0171 & $<.0001$ & $<.00010 .2634$ & \\
\hline
\end{tabular}

* This table shows the results of the Treynor-Mazuy (TM) market-timing measures for the buy-and-hold, simple trading, and complex trading strategies. The simple trading rule is that investors will shift their money into a money market fund (or deposits) on Friday to avoid the negative Monday return and then switch it back to the riskier mutual fund on Monday. The complex trading rule is that investors will shift their money into a money market fund (or deposits) to avoid the days of the weeks when average returns of the mutual fund class are historically negative and then switch it back to the riskier mutual fund.

Table 8. Henriksson and Merton (HM) measures for returns of buy-and-hold strategy and two trading strategies.

\begin{tabular}{|c|c|c|c|c|c|c|c|c|c|c|c|}
\hline \multirow[t]{2}{*}{ Asset classes } & \multicolumn{4}{|c|}{ Buy and Hold strategy } & \multicolumn{4}{|c|}{ Simple trading strategy } & \multicolumn{3}{|c|}{ Complex trading strategy } \\
\hline & $\alpha$ & $\beta$ & $\gamma$ & $R^{2}$ & $\alpha$ & $\beta$ & $\gamma$ & $R^{2}$ & $\beta$ & $\gamma$ & $R^{2}$ \\
\hline \multirow[t]{2}{*}{ All funds } & 0.0244 & 0.9344 & -0.0269 & 0.7421 & 0.0150 & 0.6590 & 0.0351 & 0.5378 & 0.02940 .5012 & 0.0294 & 0.4138 \\
\hline & $<.0001$ & $<.0001$ & $<.0001$ & & $<.0001$ & $<.0001$ & $<.0001$ & & $<.0001<.0001$ & $<.0001$ & \\
\hline \multirow[t]{2}{*}{ China-related } & 0.0203 & 0.9655 & -0.0250 & 0.7194 & 0.0143 & 0.6397 & 0.0273 & 0.4727 & 0.02350 .4941 & 0.0297 & 0.3762 \\
\hline & 0.0040 & $<.0001$ & $<.0001$ & & 0.0569 & $<.0001$ & 0.0693 & & $0.0010<.0001$ & 0.0505 & \\
\hline \multirow[t]{2}{*}{ General } & 0.0217 & 0.9285 & -0.0242 & 0.7550 & 0.0108 & 0.6572 & 0.0378 & 0.5505 & 0.02560 .4996 & 0.0313 & 0.4228 \\
\hline & $<.0001$ & $<.0001$ & $<.0001$ & & $<.0001$ & $<.0001$ & $<.0001$ & & $<.0001<.0001$ & $<.0001$ & \\
\hline \multirow[t]{2}{*}{ Mid-and-small } & 0.0378 & 0.9280 & -0.0375 & 0.6883 & 0.0285 & 0.6471 & 0.0307 & 0.4921 & $\begin{array}{lll}0.0436 & 0.4928\end{array}$ & 0.0227 & 0.3781 \\
\hline & $<.0001$ & $<.0001$ & $<.0001$ & & $<.0001$ & $<.0001$ & 0.0002 & & $<.0001<.0001$ & 0.0027 & \\
\hline \multirow[t]{2}{*}{ Special } & 0.0260 & 0.9147 & -0.0324 & 0.7226 & 0.0110 & 0.6480 & 0.0407 & 0.5337 & $\begin{array}{lll}0.0288 & 0.4929\end{array}$ & 0.0322 & 0.4094 \\
\hline & $<.0001$ & $<.0001$ & $<.0001$ & & 0.1076 & $<.0001$ & 0.0021 & & $<.0001<.0001$ & 0.0156 & \\
\hline \multirow[t]{2}{*}{ Technology } & 0.0219 & 0.9654 & -0.0246 & 0.7388 & 0.0187 & 0.6807 & 0.0322 & 0.5319 & $\begin{array}{lll}0.0310 & 0.5177\end{array}$ & 0.0296 & 0.4103 \\
\hline & $<.0001$ & $<.0001$ & $<.0001$ & & $<.0001$ & $<.0001$ & $<.0001$ & & $<.0001<.0001$ & $<.0001$ & \\
\hline \multirow[t]{2}{*}{ Value } & 0.0334 & 0.8854 & -0.0358 & 0.8070 & 0.0170 & 0.6267 & 0.0226 & 0.5886 & 0.03690 .4774 & 0.0180 & 0.4541 \\
\hline & $<.0001$ & $<.0001$ & $<.0001$ & & 0.0114 & $<.0001$ & 0.1009 & & $<.0001<.0001$ & 0.1941 & \\
\hline
\end{tabular}

* This table shows the results of the Henriksson-Merton (HM) market-timing measures for the buy-and-hold, simple trading, and complex trading strategies. The simple trading rule is that investors will shift their money into a money market fund (or deposits) on Friday to avoid the negative Monday return and then switch it back to the riskier mutual fund on Monday. The complex trading rule is that investors will shift their money into a money market fund (or deposits) to avoid the days of the weeks when average returns of the mutual fund class are historically negative and then switch it back to the riskier mutual fund.

arrival and processing of macroeconomic news. We first separate the stocks in the Taiwan stock market into deciles (at the beginning of each year) according to their market value. The fund returns are then regressed on the concurrent and one-day lagged returns of stocks from deciles 10 , as in

$$
R_{i t}=\delta_{o j}+\delta_{1 i} R_{10 t}+\delta_{2 i} R_{10 t-1}+\varepsilon_{i t}^{*},
$$

returns of decile 10 and $\delta_{1 i}$ and $\delta_{2 i}$ measure the response of fund i to $R 10 t$ and $R 10 t-1$.

The fitted values from equation (6) capture the seasonality at the arrival of macroeconomic news under the assumption that there is no seasonality in information processing. Once captured by the fitted values, the residuals are regressed on Monday and Friday as follows:

where $R_{10 t}$ and $R_{10 t-1}$ are the concurrent and one-lagged 
Table 9. Weekend effect after considering macroeconomic news

\begin{tabular}{|c|c|c|c|c|c|c|c|}
\hline & $\begin{array}{c}\text { All } \\
\text { funds }\end{array}$ & China-related & General & Mid-and-small & Special & Technology & Value \\
\hline \multicolumn{8}{|c|}{$R_{i t}=\delta_{o j}+\delta_{1 j} R_{10 t}+\delta_{1 j} R_{10 t-1}+\varepsilon_{i t}^{*}$} \\
\hline \multirow[t]{2}{*}{ Intercept } & 0.0999 & 0.1597 & 0.1040 & 0.1010 & 0.0021 & 0.1094 & 0.1705 \\
\hline & $<.0001$ & 0.0209 & $<.0001$ & 0.0176 & 0.9636 & 0.0006 & 0.0051 \\
\hline \multirow[t]{2}{*}{$\mathrm{R}_{10 \mathrm{t}}$} & 0.7932 & 0.7769 & 0.7919 & 0.7451 & 0.7691 & 0.8440 & 0.7803 \\
\hline & $<.0001$ & $<.0001$ & $<.0001$ & $<.0001$ & $<.0001$ & $<.0001$ & $<.0001$ \\
\hline \multirow[t]{2}{*}{$\mathrm{R}_{10 \mathrm{t}-1}$} & 0.9078 & 0.8749 & 0.9072 & 0.8902 & 0.8814 & 0.9434 & 0.8523 \\
\hline & $<.0001$ & $<.0001$ & $<.0001$ & $<.0001$ & $<.0001$ & $<.0001$ & $<.0001$ \\
\hline \multirow[t]{2}{*}{$\begin{array}{r}\text { Adjusted } \\
\mathrm{R}^{2} \\
\end{array}$} & 0.2572 & 0.2510 & 0.2587 & 0.2255 & 0.2659 & 0.2644 & 0.3229 \\
\hline & \multicolumn{7}{|c|}{$\varepsilon_{i t}^{*}=\alpha_{0}^{*}+\alpha_{1}^{*} D M O N_{t}+\alpha_{2}^{*} D F R I_{t}+\mu_{i t}^{*}$} \\
\hline \multirow[t]{2}{*}{ Intercept } & -0.1215 & 0.0559 & -0.1242 & -0.1413 & -0.1270 & -0.1270 & -0.0171 \\
\hline & $<.0001$ & 0.4425 & $<.0001$ & 0.0013 & 0.0077 & 0.0001 & 0.7877 \\
\hline \multirow[t]{2}{*}{$D M O N$} & -0.1750 & -0.1904 & -0.1714 & -0.1922 & -0.1335 & -0.1963 & -0.1690 \\
\hline & $<.0001$ & 0.0043 & $<.0001$ & $<.0001$ & 0.0016 & $<.0001$ & 0.0127 \\
\hline \multirow[t]{2}{*}{$D F R I$} & -0.0612 & -0.1379 & -0.0616 & -0.0700 & -0.0743 & -0.0438 & -0.0685 \\
\hline & $<.0001$ & 0.0502 & $<.0001$ & 0.0559 & 0.1118 & 0.1350 & 0.3168 \\
\hline $\begin{array}{r}\text { Adjusted } \\
\mathrm{R}^{2}\end{array}$ & 0.0004 & 0.0005 & 0.0004 & 0.0004 & 0.0002 & 0.0005 & 0.0003 \\
\hline
\end{tabular}

* This table shows that the arrival patterns of macroeconomic news contribute to the weekend effects for fund returns. The fund returns are first regressed on the concurrent and one-day lagged returns of stocks from decile 10. The residuals are then regressed on the Dummy of Monday and Friday.

$$
\varepsilon_{i t}^{*}=\alpha_{0}^{*}+\alpha_{1}^{*} D M O N_{t}+\alpha_{2}^{*} D F R I_{t}+\mu_{i t}^{*}
$$

where $\varepsilon_{i t}$ is the error term and $\alpha_{1}^{*}\left(\alpha_{2}^{*}\right)$ is the coefficient that captures the Monday (Friday) effect for fund returns net of such effects in the arrival of macroeconomic news (DFRI is denoted as Saturday for the year prior to 2000). If the fund returns are more negative on Mondays, or positive on Fridays, after year 2000 (Saturday before the year 2000) than on other weekdays, and if returns on large firms' stocks reflect macroeconomic news, $\alpha_{1}\left(\alpha_{2}\right)$ in equation (2) will be more negative (positive) than $\alpha_{1}^{*}\left(\alpha_{2}^{*}\right)$ in equation (7). The results are shown in Table 9.

The coefficients $\delta_{1 i}$ and $\delta_{2 i}$ capture the fund's contemporaneous and lagged response to macroeconomic news. As shown in Table 9 , both $\delta_{1 i}$ and $\delta_{2 i}$ are significantly positive for all fund types. The positive $\delta_{2 i}$ shows some evidence of delayed response of fund returns to lagged negative returns from macroeconomic news. Panel B of Table 9 shows that, after considering the effects from macroeconomic news, the coefficients in the dummy Monday are less negative and the coefficients in dummy the Friday (Saturday before year 2000) are less positive than those where the arrival of macroeconomic news is considered. That is, in comparison with the $\alpha_{1}^{*}$ in Table 9 and the $\alpha_{1}$ in Table 2, it is found that $\alpha_{1}^{*}$ is closer to zero than $\alpha_{1}$. Similarly, $\alpha_{2}^{*}$ is closer to zero than $\alpha_{2}$. This phenomenon holds for all types of funds, indicating that the arrival pattern of macroeconomic news contributes to weekend effects for fund returns, which is similar to Chang, Pinegar, and Ravichandran [8]. However the still significantly negative $\alpha_{1}^{*}$ reveals that weekend effects exist even after taking the arrival of macroeconomic news into consideration.

\section{CONCLUSION}

The weekend effect for stock returns provides no operational trading strategy because of transaction costs. However, transaction costs may be escaped by trading mutual funds. Daily return observations from six categories of Taiwan mutual funds are used to analyze the potential profitability of their returns by capitalizing the weekend effect. The results suggest that the weekend trading strategies, both simple and complex, can increase returns and moderate risk. Investors can obtain positive risk-adjusted returns as indicated by higher Sharpe, Treynor, and Jensen measures by following a weekend trading strategy. In addition, the Treynor-Mazuy and Henriksson-Merton market timing models suggest that, contrary to the buy-and-hold strategy, the weekend strategy produces positive timing measures. Finally, the arrival pattern of macroeconomic news can only partially explain weekend effects on fund returns.

The profitability of a trading strategy based on the weekend effect, although it benefits some individual investors, may not be in the interest of other fund investors. In addition, fund families may also incur extra administrative costs due to such frequent trading, including larger spreads and commissions for 
buying and selling securities, which would necessitate rebalancing the portfolio or a lead to potential deviation from an optimal portfolio. Therefore, some fund families have recently placed limitations on the frequency of trading, or imposed additional fees for investing in less than three months. Nevertheless, given the profitability of the timing purchase-and-sales strategy, as argued by Mazumder, Miller, and Varela [42], fund families should eventually deal with frequent trading and design related products accordingly.

\section{REFERENCES}

1. Agrawal, A. and Tandon, K., "Anomalies or illusions? Evidence from stock markets in eighteen countries," Journal of International Money and Finance, Vol. 13, No. 1, pp. 83-106 (1994).

2. Aggarwal, R. and Rivoli, P., "Seasonal and day-of-the-week effects in four emerging stock markets," Financial Review, pp. 541-550 (1989).

3. Ariel, R.A., "A monthly effect in stock returns," Journal of Financial Economics, Vol. 18, No. 1, pp. 161-174 (1987).

4. Bollen, N. P. B. and Busse, J. A., "On the timing sbility of mutual fund managers," Journal of Finance, Vol. 56, No. 3, pp. 1075-1094 (2001).

5. Carhart, M. M., Kaniel, R., Musto, D. K., and Reed, A. V., "Leaning for the tape: evidence of gaming behavior in equity mutual funds," Journal of Finance LVII, pp. 661-693 (2002).

6. Cha, H. J. and Lee, B. S., "The market demand curve for common stocks: evidence from equity mutual fund flows," Journal of Financial and Quantitative Analysis, Vol. 36, pp. 195-220 (2001).

7. Chan, S., Leung, W. K., and Wang, K., "The impact of institutional investors on the monday seasonal," Journal of Business, forthcoming (2003).

8. Chang, E., Pinegar, M., and Ravichandran, R., "International evidence on the robustness of the day-of-the-week effect," Journal of Financial and Quantitative Analysis, Vol. 28, No. 4, pp. $497-513$ (1993).

9. Chang, E. C., Pinegar, J. M., Ravichandran, R., "US day-of-the-week effects and asymmetric responses to macroeconomic news," Journal of Banking \& Finance, Vol. 22, No. 5, pp. 513-534 (1998).

10. Chen, H. and Singal, V., "Role of speculative short sales in price formation: The case of the weekend effect," Journal of Finance, Vol. 58, No. 2, pp. 685-706 (2003).

11. Chow, E. H., Hsiao, P., and Solt, M. E., "Trading returns for the weekend effect using intraday data," Journal of Business, Finance and Accounting, Vol. 24, No. 3, pp. 425-444 (1997).

12. Compton, W. S. and Kunkel, R. A., "A tax-free rxploitation of the weekend effect: a "switching" strategy in the college retirement equities fund (CREF)," American Business Review, Vol. 17, No. 2, pp. 17-23 (1999).

13. Connolly, R. A., "An examination of the robustness the weekend effect," Journal of Financial and Quantitative Analysis, Vol. 24, No. 2, pp. 133-169 (1989).

14. Connolly, R. A., "A posterior odds analysis of the weekend effect," Journal of Econometrics, Vol. 49, pp. 51-104 (1991).

15. Dubois, M. and Louvet, P., "The day-of-the-week effect: international evidence," Journal of Banking and Finance, Vol. 20, No. 9, pp. 1463-1484 (1996)

16. Damodaran, A., "The weekend effect in information releases: a study of earnings and dividend announcements," Review of Financial Studies, Vol. 2, pp. 607-623 (1989).

17. Edelen, R. M., "Investor flows and the assessed performance of open-end mutual funds," Journal of Financial Economics, Vol. 53, pp. 439-466 (1999).

18. Edelen, R. M. and Warner, J. B., "Aggregate price effects of institutional trading: a study of mutual fund flow and market returns," Journal of Financial Economics, Vol. 59, No. 2, pp. 195-220 (2001).

19. Firth, M., "The transmission of corporate financial information across national borders and equity market linkages," Review of Accounting Studies, Vol. 1, No. 4, pp. 309-337 (1996).

20. Freeman, R. N. and Tse, S. Y., "A nonlinear model of security price responses to unexpected earnings," Journal of Accounting Research, Vol. 30, No. 2, pp. 185-209 (1992)

21. French, K., "Stock returns and the weekend effect," Journal of Financial
Economics, Vol. 8, No. 1, pp. 55-69 (1980)

22. Flannery, M., and Protopapadakis, A., "From T-Bills to common stocks: Investigating the generality of intra-week return seasonality," Journal of Finance, Vol. 53, No. 2, pp. 431-450 (1988).

23. Gibbons, M. and Hess, P., "Day of the week effects and asset returns," Journal of Business, Vol. 54, No. 4, pp. 579-596 (1981).

24. Henriksson, R. D. and Merton, R. C., "On market timing and investment performance: statistical procedures for evaluating forecasting skills," Journal of Business, Vol. 54, pp. 513-534 (1981).

25. Ho, Y. K., "Stock return seasonality in Asia pacific markets," Journal of International Financial Management and Accounting, Vol. 2, No. 1, pp. 47-77 (1990)

26. Han, J. C. Y. and Wild, J. J., "Unexpected earnings and intra industry information transfers: further evidence," Journal of Accounting Research, Vol. 28, No. 1, pp. 211-219 (1990).

27. Jaffe, J. and Westerfield, R., "The weekend effect in common stock returns: the international evidence," Journal of Finance, Vol. 40, No. 2, pp 433-454 (1985).

28. Jaffe, J. and Westerfield, R., "Patterns in Japanese common stock returns: day of the week and turn of the year effects," Journal of Financial and Quantitative Analysis, Vol. 20, No. 2, pp. 261- 272 (1985).

29. Jaffe, J., and Westerfield, R., "Is there a monthly effect in stock market returns?" Journal of Banking and Finance, Vol. 13, pp. 237-244 (1989).

30. Jensen, M. C., "The performance of mutual funds in the period 1945-1964," Journal of Finance, Vol. 23, pp. 389-416 (1968).

31. Kamara, A., "New evidence on the monday seasonal in stock returns," Journal of Business, Vol. 70, No. 1, pp. 63-84 (1997).

32. Kato, K., "Weekly patterns in Japanese stock returns," Management Science, Vol. 36, pp. 1031-1043 (1990).

33. Keim, D., "Size-related anomalies and stock return seasonality: further empirical evidence," Journal of Financial Economics, Vol. 12, pp. 13-32 (1983).

34. Keim, D. B. and Stambaugh, R. F., "A further investigation of the weekend effect in stock returns," Journal of Finance, Vol. 39, No. 3, pp. 819-835 (1984).

35. Keim, D., "Daily returns and size-related premiums: one more time," The Journal of Portfolio Management, Vol. 13, pp. 41-47 (1987).

36. Kim, S.-W., "Capitalizing on the weekend effect," Journal of Portfolio Management, Vol. 14, No. 3, pp. 59-63 (1988).

37. Lakonishok, J. and Levi, M., "Weekend effects in stock returns: a note," Journal of Finance, Vol. 37, No. 3, pp. 883-889 (1982).

38. Lakonishok, J. and Smidt, S., "Are seasonal anomalies real? A ninety-year perspective," Review of Financial Studies, Vol. 1, pp. 403-425 (1988).

39. Lakonishok, J. and Maberly, E., "The weekend effect: trading patterns of individual and institutional investors," Journal of Finance, Vol. 45, No. 1, pp. 231-43 (1990).

40. Liano, K. and Gup, B.E., "The day-of-the-week effect in stock returns over business cycles," Financial Analysts Journal, Vol. 45, No. 4, pp. 74-77 (1989).

41. Miller, E. M., Prather, L. J., and Mazumder, M. I., "Day-of-the-week effects among mutual funds," Quarterly Journal of Business and Economics, Vol. 42, pp. 113-128 (2003).

42. Mazumder, M. I., Miller, E. M., and Varela, O. A., "The weekend trading profitability: evidence from international mutual funds," University of New Orleans, Department of Economics and Finance, Working Papers (2005)

43. Newey, W. K. and West, K. D., "Hypothesis testing with efficient method of moments estimation," International Economic Review, Vol. 28, No. 3 pp. 777-787 (1987).

44. Neal, R. and Wheatley, S. M., "Adverse selection and bid-ask spreads: evidence from closed-end funds," Journal of Financial Markets, Vol. 1, pp. 121-149 (1998).

45. Neal, R. and Wheatley, S. M., "Do measures of investor sentiment predict returns?" Journal of Financial and Quantitative Analysis, Vol. 33, pp. 523-547 (1998).

46. Ogden, J. P., "Turn-of-month evaluations of liquid profits and stock returns: a common explanation for the monthly and january effects,' Journal of Finance, Vol. 45, No. 4, pp. 1259-1272 (1990).

47. Richard T. B. and DeGennaro, R. P., "The impact of delivery terms on stock return volatility," Journal of Financial Services Research, Vol. 3 , No. 1, pp. 55-76 (1989). 
48. Sharpe, W. F., "Mutual fund performance," Journal of Business, Vol. 39, pp. $119-138$ (1966).

49. Sias, R., and Starks, L., "The day-of-the-week anomaly: the role of institutional investors," Financial Analysis Journal, Vol. 51, pp. 58-67 (1995).

50. Treynor, J. L., "How to rate management of investment funds," Harvard Business Review, Vol. 43, pp. 63-75 (1965).
51. Treynor, J. L. and Mazuy, K. K., "Can mutual funds outguess the market?" Harvard Business Review, Vol. 44, pp. 131-136 (1966).

52. Wang, K., Li, Y., and Erickson, J., "A new look at the monday effect," Journal of Finance, Vol. 52, No. 5, pp. 2171-2186 (1997).

53. Zweig, J., "Watch out for the year-end fund flimflam," Money, Vol. 26, No. 11, pp. 130-132 (1997). 